\title{
Typifications and combinations in the Ebenaceae of Peninsular Malaysia and Singapore
}

\author{
R. P. J. de Kok ${ }^{1} \&$ C. Puglisi ${ }^{2}$ (i)
}

Summary. Many of the current and synonymous names applied to the species of Diospyros L. (Ebenaceae) from Peninsular Malaysia and Singapore lack a type. Here we designate lectotypes and two neotypes and establish the correct combinations for the taxa belonging to the species hitherto known as Diospyros pilosanthera.

Key Words. Diospyros, ebonies, lectotype, Malay Peninsula, Malesia, neotype, nomenclature.

\section{Introduction}

Diospyros is being revised for the Flora of Peninsular Malaysia and the Flora of Singapore. In Peninsular Malaysia we recognise 65 species of Diospyros, 13 of which are endemic, whereas in Singapore there are 15 native species, none of them endemic to the island. Full descriptions, keys and notes on distribution and habitat will be given in the forthcoming accounts of the Ebenaceae in the Flora of Peninsular Malaysia and in the Flora of Singapore.

During the preparation of these accounts, it became clear that many of the names adopted in the region needed to be lectotypified, and that the lack of formal types resulted in species being incorrectly recognised and inappropriately named. The aims of this paper, therefore, are to designate the type specimens of accepted and synonymous names, and to establish correct denominations as relevant. We chose to publish these amendments independently from the two Flora accounts under way in order to benefit from a stricter nomenclatural peer-review, a freer format that allowed us to justify our choices and provide additional details, and an earlier publication, so that new taxonomic investigations can start using established names and types consistently.

Almost all species of Diospyros are dioecious. The majority of the fertile collections that we have seen thus far are in fruit, and some species are in fact only known from fruiting material. Of the flowering specimens, most are male, and the female flowers are frequently poorly known or unknown. A likely reason for this gap in the collections is perhaps a bias towards the phase that lasts longer, which in this case is the fruiting season. Furthermore, in many species the female inflorescences are shorter and fewer-flowered than their male equivalents, and thus less conspicuous among the foliage. The profusion of fruiting material shows that the female plants are not uncommon, therefore they simply are under-collected when in flower. Considering the prevalence of fruiting material in herbaria and in literature, whenever possible, we have given preference to fruiting specimens when designating a lectotype.

This work is based on herbarium collections from Peninsular Malaysia and Singapore currently housed at the Natural History Museum, London (BM, herbarium codes from Thiers, continuously updated), Herbarium Bogoriense (BO), the Royal Botanic Garden Edinburgh (E), the Royal Botanic Gardens, Kew ( $\mathrm{K}$ and $\mathrm{K}-\mathrm{W}$ ), the Forest Research Institute of Malaysia (KEP) and the Singapore Botanic Gardens (SING). Type material from other institutions was seen via JSTOR Global Plants (https://plants.jstor.org/plants) and accessed between December 2018 and April 2019. Types that are cited in literature but were not available online for verification, are listed as "not seen".

\section{Synonymisations and nomenclatural adjustments}

There has been some uncertainty over the status of Diospyros pilosanthera Blanco var. oblonga (Wall. ex G.Don) $\mathrm{Ng}$ and its basionym D. oblonga Wall. ex G.Don. Ever since Ng (1977) reduced Diospyros oblonga to a variety of $D$. pilosanthera, the taxon has been inconsistently treated as a species or a variety by subsequent authors (Chong et al. 2009; Keng 1990; Phengklai 1981; Turner 1993, 1995; Wong et al. 2013). The taxonomic investigation carried out during the preparation of the Flora accounts for Peninsular Malaysia and Singapore has brought up the issue once again, and we concluded that the taxon named

\footnotetext{
Accepted for publication 9 January 2020. Published online 4 June 2021

1 Singapore Botanic Gardens, National Parks Board, 1 Cluny Road, Singapore, 259569, Singapore.

2 Herbarium, Royal Botanic Gardens, Kew, Richmond, TW9 3AE, UK. e-mail: c.puglisi@kew.org
} 
Diospyros oblonga or D. pilosanthera var. oblonga is synonymous with $D$. pilosanthera.

According to the International Code of Nomenclature (Turland et al. 2018), the name that takes priority is the oldest, however, Diospyros oblonga and $D$. pilosanthera were published validly in the same year. Diospyros oblonga was validly published in the fourth volume of Don's General History of the Dichlamydeous plants, which was issued in 1837 in parts that cannot be dated individually (Stafleu \& Cowan 1976). Given that D. oblonga is presented at page 40 , it could be assumed that the issue in which the name was included was released early in the year. The name $D$. pilosanthera was also established in 1837 but, according to Stafleu \& Cowan (1976), Blanco's Flora de Filipinas reached other herbaria only at the end of the year. We do not know if the publication was circulated in the region earlier, potentially before Don's publication. Based on the current knowledge, and admittedly making several assumptions, we believe that the name Diospyros oblonga was published first, or at least should be accepted as the oldest name. Accordingly, a series of new combinations need to be made, and these changes are summarised here. New typifications are reported in the following section.

Diospyros oblonga Wall. ex G.Don Don (1837: 40); Diospyros pilosanthera Blanco var. oblonga (Wall. ex G.Don) Ng (1977: 237). Type: Peninsular Malaysia, Penang, Aug. 1822, Wallich s.n. [EICH no. 4124] (lectotype K-W [K001038214] further details in the typification section).

Diospyros pilosanthera Blanco (1837: 304), synon. nov. Type: Philippines, Batangas Prov., Luzon, 11 Feb. 1915, Ramos, Species Blancoanae No. 820. Further details in the typification section.

Diospyros oblonga var. chikusensis $(\mathrm{Ng})$ de Kok $\mathcal{E}^{\circ}$ C.Puglisi comb. nov. Type: Peninsular Malaysia, Perak, Chikus Forest Reserve, 18 Sept. 1926, Speldewinde KEP 11749 (holotype KEP [11423], isotype SING [SING0248146]).

http://www.ipni.org/urn:lsid:ipni.org:names:77216007-1

Diospyros pilosanthera var. chikusensis $\mathrm{Ng}$, Malaysian Forester 40: 236 (1977).

Diospyros oblonga var. helferi (C.B.Clarke) de Kok $\mathcal{E}^{\circ}$ C.Puglisi comb. et stat. nov. Type: Tenasserim or Andamans, Helfer 3632 (lectotype K [no barcode] designated by Singh (2005: 201)). http://www.ipni.org/urn:lsid:ipni.org:names:77216008-1

Diospyros pilosanthera var. helferi (C.B.Clarke) Bakh., Bakhuizen van den Brink, Bull. Jard. Bot. Buitenzorg ser. 3, 15: 246 (1938); Diospyros helferi C.B.Clarke, Fl. Brit. India [J.D. Hooker] 3: 569 (1882).

Diospyros oblonga var. nurii $(\mathrm{Ng})$ de Kok $\mathcal{E}$ C.Puglisi comb. nov. Type: Peninsular Malaysia, Selangor, Kuala Langat Forest Reserve, 27 Oct. 1975, Kochummen FRI 23148 (holotype KEP [11396]; isotype K [K000792586]).

http://www.ipni.org/urn:lsid:ipni.org:names:77216009-1

Diospyros pilosanthera var. nurii $\mathrm{Ng}$, Malaysian Forester 40 : 238 (1977).

\section{Typifications}

Diospyros adenophora Bakh. (Bakhuizen van den Brink 1933: 164). Type: Peninsular Malaysia, Kota Glanggi, 5 Aug. 1929, Henderson 22468 (lectotype BO [sheet BO-1358027] selected here; isolectotypes $\mathrm{K}$ [K000792574, K000792575], MICH [MICH1218172], SING [SING0052853], US [US00344756], FHO (not seen, fide $\mathrm{Ng}$ 1977)). Accepted name.

In the original description of this species, two distinct gatherings were mentioned: Ridley 13051 and Henderson 22468. The only specimen of Ridley 13051 we located is at SING [SING0052852], whereas multiple specimens of Henderson 22468 were seen in different herbaria.

Diospyros andamanica (Kurz) Bakh. (Bakhuizen van den Brink 1937: 74); Ebenus andamanica (Kurz) Kuntze (1891: 408); Maba andamanica Kurz (1876: 138); "Macreightia andamanica Kurz" (1870: 42) (nom. nud.); Kurz (1871: 74) (pro syn.). Type: India, Nicobar Islands, Tillangchong, Jelinek 105 [Expedition Novara 148] (lectotype W [W0043143]) selected here). Accepted name.

When Kurz described the new species Maba andamanica, listing "Macreightia andamanica", a nomen nudum he had published a few years before, in synonymy, he cited the collection Novara 148 /Jelinek 105, from Tillangchong, in the Nicobar Archipelago. Both number series refer to one single gathering: Jelinek was part of the 1857 - 59 expedition of the Austrian frigate Novara (van Steenis-Kruseman 1950), and collections were catalogued under a Novara number series, as well as the collectors' own series. Here we designate the individual lectotype. 
Diospyros apiculata Hiern (1873: 186). Type: Peninsular Malaysia, Penang, [South?] Hill, Maingay s.n. [Kew Distrib. no. 1514] (lectotype K [K000792352] first step selected by $\mathrm{Ng}$ (1977: 212), second step selected here; isolectotypes $\mathrm{BM}$ [no barcode], $\mathrm{K}$ [no barcode]). Accepted name.

In the original description of this species, the only gathering mentioned was Maingay 1514 from Penang, in Peninsular Malaysia. A first step lectotypification was made by $\mathrm{Ng}$ (1977), who designated the herbarium. Here, we establish the individual lectotype among the two sheets found at $\mathrm{K}$.

Diospyros areolata King E Gamble (1905: 228). Type: Peninsular Malaysia, Perak, Larut, April 1884, King's Collector 5813 (lectotype SING [SING0052908] selected here; isolectotypes BM [no barcode], K [K000792561, no barcode], SING [SING0052909, SING0052910, SING0246334]). Accepted name.

In the original description of this species, two distinct gatherings were mentioned: King's Collector 5813 and Scortechini 476, both from Perak. We chose to lectotypify this name on the former collection. The latter, Scortechini 476, is present at P [P00721509] and K [K000792560, K000792562].

Diospyros bejaudii Lecomte (1929: 430). Type: Cambodia, 18 April 1929, Béjaud 23 (lectotype P [P00721441] selected here; isolectotype P [P02141496]). Accepted name.

In the original description of this species, the author referred to a collection made by Béjaud in Kompong Cham, Cambodia. The only specimens clearly citing this locality in the label (Béjaud 26, found at $\mathrm{P}$ [P00721439, P00721440]) were received by the herbarium in Paris in 1930, the year after the publication of this new species. Here we designate as the lectotype one of the few other specimens of Diospyros bejaudii collected by Béjaud in Cambodia and received by the Paris herbarium in 1929.

Diospyros bibracteata Bakh. (Bakhuizen van den Brink 1933: 165). Type: Peninsular Malaysia, Pahang, Tembeling, 25 May 1931, Henderson 24512 (lectotype BO [sheet 1358035] selected here; isolectotypes BO [sheet 1360671], K [K000792566, K000792567], MICH [MICH1218175], SING [SING0246184]). Accepted name.
The original description of Diospyros bibracteata included the citation of a single collection. Here we designate one of the six specimens we found as the lectotype.

Diospyros bilocularis Oliv. (Oliver 1894: t. 2336). Type: Singapore, Jungle by the Botanic Gardens, 1891, Ridley 2755 (lectotype K [K000792367] selected here; isolectotypes BM [no barcode], E [E00318416], K [K000792368, K000792369]). Synonym of Diospyros maingayi (Hiern) Bakh.

A single collection was cited in the original description of this taxon, here we designate one of the five specimens we located as the lectotype.

Diospyros brachiata King E Gamble (1905: 224). Type: Peninsular Malaysia, Penang, Waterfall valley, 1888, Curtis 1453 (lectotype K [K000792583] selected here; isolectotype SING [SING0052913]). Synonym of Diospyros hasseltii Zoll.

The original publication cited three gatherings from Penang: Curtis 1453, 1454 and 10230. Later authors (Bakhuizen van den Brink 1938; Ng 1977) have subsequently attributed the latter collection to Ridley instead, and in fact we were only able to find Ridley 10230, collected in Penang Hill in 1899, at SING [SING0052915]. Curtis' collection numbers and localities in that period were similar to Ridley's, and to the best of our knowledge we accept that King \& Gamble's designation was mistaken and later corrected by Bakhuizen van den Brink. Under Curtis 1453 at least two different collections were found, one made in 1888 (K [K000792583], SING [SING0052913]) and a later one from May 1892 ([SING0052914, SING246534]). The only specimen of Curtis 1454 we were able to find (SING [SING0052916]) was also collected in 1892. Considering the number of recognised duplicates and the conditions of the specimen, we choose the Curtis 1453 specimen at $\mathrm{K}$ as the lectotype.

Diospyros brandisiana Kurz (1871: 72). Type: Myanmar, Domdamee Forests, March 1862, Brandis 951 (lectotype HBG [HBG507427] selected here). Accepted name.

Kurz (1871) cited only one collection in the original publication of Diospyros brandisiana: Burma, Domdamee Forest, Dr. Brandis s.n. Only one specimen of this gathering could be found and is here designated as the lectotype. 
Diospyros buxifolia (Blume) Hiern (1873: 218); Leucoxylum buxifolium Blume (1827: 1169). Type: Indonesia, Java, Blume s.n. (lectotype L [L0005887] first step designated by $\mathrm{Ng}$ (1977: 215), second step selected here; isolectotype L [L00055886 (female plants only)]; possible isolectotypes L [L00055888, L00055889, L0005890, L0005891]). Accepted name.

Blume's original description (1827) of the genus Leucoxylum was based on the observation of both male and female plant material but contained no specimen citations. Ng's designation (1977) of "Blume s.n. (L) Java", was not exhaustive because there are at least six sheets of relevant Blume specimens at $\mathrm{L}$. We chose to designate as the type a female (fide Bakhuizen van den Brink) specimen. The specimen barcoded [L00055886] is a mixed collection of male and female branchlets and therefore only partially a type. We were unable to determine the sex of the other specimens from images, therefore we are listing them as possible isolectotypes.

Diospyros caliginosa Ridl. (Ridley 1893: 318). Type: Peninsular Malaysia, Kuala Tembeling, 12 Aug. 1891, Ridley 2268 (lectotype SING [SING0052303] first step selected by $\mathrm{Ng}$ (1977: 216), second step selected here). Synonym of Diospyros cauliflora Blume.

In the original description of this species, Ridley (1893) cited two localities where he presumably collected the original material, Kota Glanggi and Kwala Tembeling, in Peninsular Malaysia. A lectotypification was initiated by $\mathrm{Ng}$ (1977), when he designated Ridley 2268 from Kwala Tembeling as the type. Here we complete it with the herbarium designation.

Diospyros carpinifolia (Ridl.) Bakh. (Bakhuizen van den Brink 1933: 162); Maba carpinifolia Ridl. in BodenKloss (1926: 73). Type: Indonesia, Sumatra, Siberut, 23 Sept. 1924, Boden-Kloss 14564 (lectotype K [K000792514] selected here). Synonym of Diospyros andamanica (Kurz) Bakh.

Ridley's description of Maba carpinifolia was based on the collection Boden-Kloss 14564 from Sumatra, Indonesia. According to the Cyclopaedia of Malesian collectors (van Steenis-Kruseman 1950), Boden-Kloss' collections from the Mentawai Islands were deposited primarily in $\mathrm{BO}$, however, we were only able to find a specimen at $\mathrm{K}$, which is therefore designated as the lectotype.
Diospyros cauliflora Blume (1826: 668). Type: Indonesia, Java, Gunung Parang, Blume s.n. (lectotype L [L0005903] first step selected by $\mathrm{Ng}$ (1977: 216), second step selected here; possible isolectotypes L [L0005902, L0005899]). Accepted name.

Blume (1826) did not give any information about the original material upon which the description of this taxon was based. Later, $\mathrm{Ng}$ (1977) made an initial lectotypification by stating that the type specimen (Blume s.n. from Java) was housed at L. We found several specimens at $\mathrm{L}$ which could potentially be designated as lectotype: [L0005899], [L0005900], [L0005901], [L0005902], [L0005903] and [L0005904]. Of these, only three sheets (L0005902, L0005903 and L0005899) have original collection data (Java, G. Parang). Here we designate the nicest specimen as the lectotype and the others as possible isolectotypes.

Diospyros clavigera C.B.Clarke (1882: 558). Type: Peninsular Malaysia, Malacca, 1845, Griffith s.n. [Kew Distrib. no. 3635] (lectotype K [K000792595] selected here; possible isolectotype K [K000792592 or K000792593]). Accepted name.

In the original description of Diospyros clavigera, Clarke (1882) cited two collections from Malacca: Griffith s.n. [Kew Distrib. no. 3635] and Maingay 971. Of the first gathering, we found two specimens at K. One of them ([K000792595]) was mounted on its own sheet, while the second specimen was mounted together with another collection labelled "Ching, Oct 1842", and the two parts barcoded [K000792592] and [K000792593]. This sheet also contains a slip signed by $\mathrm{Ng}$ in 1969, with a lectotype designation which however was never effectively published either in his enumeration of Malayan Diospyros (1977) or his subsequent publications. The two different plant specimens are not clearly separated from one another. Of the second gathering, Maingay 971, we found only one specimen with the following original data: Maingay 1964 [Kew Distrib. no. 971], Malacca, [locality illegible], 28 Sept. 1865 - 66, barcode [K000792591]. We decided not to designate this as the lectotype because the specimen is not as complete as the Griffith collection, and additionally in order not to diverge too drastically from Ng's unpublished choice.

Diospyros conformis Bakh. (Bakhuizen van den Brink 1933: 167). Type: Peninsular Malaysia, Perak, Ulu Sungei Bing, 5 Aug. 1925, Hamid 10384 (lectotype KEP [10814] first step selected by $\mathrm{Ng}$ (1977: 217), second step selected here; isolectotype KEP [181353]). Accepted name. 
In the original description of this taxon the author cited only one gathering, Hamid 10384 from Perak. A later account of Malayan Diospyros ( $\mathrm{Ng} \mathrm{1977)} \mathrm{added}$ KEP as the current location of the type material. Since two specimens were found at KEP [10814, 181353], we complete this typification by designating the specimen with mature fruits as the lectotype.

Diospyros curranii Merr. (Merrill 1909: 306); Diospyros reticulata Elmer (1908: 506) (nom. illegit., later homonym). Type: Philippines, Luzon, Province of Tayabas, Lucban, May 1907, Elmer 9241 (lectotype NY [NY00334773] selected here; isolectotypes K [K000792629], L [L0005923]). Accepted name.

The original description of Diospyros reticulata (Elmer 1908) cited as the type a fruiting Elmer 9242 gathering from the Philippines, Luzon, Province of Tayabas, Lucban, May 1907. In the original publication of Diospyros curranii, the new name that was coined to replace the illegitimate later homonym, Merrill (1909) changed the number to 9241. Elmer 9242 (cf specimen $\mathrm{Z}$ [Z000021091]) is in fact a type of Litsea griseola Elmer, therefore we can only assume that Elmer's publication contained a typo, which was later corrected by Merrill. We found specimens of Elmer 9241 with label data matching those of Elmer's description. Furthermore, the NY sheet has a typed excerpt of Elmer's field notes that match extremely closely the wording used in the protologue of Diospyros reticulata, thus confirming the hypothesis of a typo. This sheet is designated here as the lectotype.

Diospyros curraniopsis Bakh. (Bakhuizen van den Brink 1933: 168). Type: Indonesia, Kalimantan, Tanah Boembae, Kampong Baroe, 2 Dec. 1928, Boschpr. bb. 13037 (lectotype BO [sheet 1358043] selected here; isolectotypes BO [sheets 1358041, 1358042, 1358044, 1358045], L [L2665642]). Synonym of Diospyros curranii Merr.

In the original description of this species, three distinct gatherings were mentioned: Endert 4883 and Boschpr. bb. 13037 from Kalimantan (Indonesia), and Elmer 21464 from Sabah (Malaysia). Only one specimen of Endert 4883 was found (BO [sheet 1354157]), while specimens of Elmer 21464 were found at BO [sheet 1354006], L [L0657385] and U [U.1284386]. There are five duplicates of Boschpr. bb. 13037 at BO and one at $\mathrm{L}$, and we chose the most flower-rich as the lectotype. "Boschpr." stands for Boschbouwproefstation, or Forest Research Institute, Buitenzorg.
Diospyros cymosa Ridl. (Ridley 1923: 293). Type: Peninsular Malaysia, Pahang, Kuantan, Telok Sesih, 23 March 1920, Yeop 864 (lectotype KEP [10917] first step selected by $\mathrm{Ng}$ (1977: 221), second step selected here; isolectotypes K [K000792588], SING [SING0052911]). Synonym of Diospyros frutescens Blume.

The original publication of this name cited a single collection, attributed to Foxworthy, with details about the locality. The only collection matching the locality information, already identified by $\mathrm{Ng}$ (1977), was in fact made by Yeop, also based at the Forest Department of the Federated Malay States at the time. Here we finalise Ng's lectotypification.

Diospyros daemona Bakh. (Bakhuizen van den Brink 1933: 169, as D. demona). Type: Peninsular Malaysia, Pahang, Bukit Chintamani, Bentong, 3 Oct. 1931, Henderson 25030 (lectotype BO [sheet 1353451] selected here; isolectotypes: BO [sheets 1353450, 1354043], FHO [not seen, fide Ng 1977], K [no barcode], MICH [MICH1218178], KEP [10807], NY [NY00335011], SING [SING0247221], US [US00344755]). Accepted name.

The type collection was already defined in the original description of this name. Here we designate the unique lectotype among the many duplicates found.

Diospyros decipiens C.B.Clarke (1882: 563); Diospyros sumatrana Miq. var. decipiens (C.B.Clarke) Bakh. (Bakhuizen van den Brink 1938: 187). Type: Malaysia, Malacca, the female only, Maingay 1703 [Kew Distrib. no. 972] (lectotype K [K000792594] selected here). Synonym of Diospyros sumatrana Miq.

Clarke (1882) stated that only the female part of the original material should be identified as Diospyros decipiens. Only one specimen of Maingay [Kew Distrib. no. 972] was found, and although made of different branchlets, it appears to be entirely female. The specimen was annotated in pencil by an anonymous hand "not the female of 972 Maingay", however we believe this to be the only existent type specimen and is here designated as the lectotype.

Diospyros dictyoneura Hiern (1873: 192). Types: Malaysia, Sarawak, Mt Mattang, near Kuching, Sept. 1866, Beccari PB 2615 (lectotype K [K000792679] selected here; isolectotypes FI [FI008993], P [P00721798]). Accepted name. 
In the original description of this species, Hiern (1873) cited two collections from Sarawak, both made by Beccari in September 1866: Beccari PB 2542 and $P B$ 2615. Of the first gathering we found one specimen at FI [FI008994] and one at K [K000792678].

Diospyros diepenhorstii Miq. (Miquel 1861: 583). Type: Indonesia, West Sumatra, Priaman, Diepenhorst HB.2176 (lectotype L [L0005929] selected here; isolectotypes BO [BO-1891444], U [U0001642]). Accepted name.

The original description of the species provided information on the locality ("Sumatra occid. in prov. Priaman") and what is presumably the initial of the collector ("D." for Diepenhorst). The collection cited above appears to match Miquel's material and the herbarium designation is here proposed.

Diospyros dumosa King $\mathcal{E}$ Gamble (Williams 1905b: 428; King \& Gamble 1905: 211). Type: Lower Siam, Gunong Loscai, (Tongkah) Junk Seylan [=Jungceylon] island, Feb. 1893, Curtis 2907 (lectotype SING [SING0052923] first step selected by $\mathrm{Ng}$ (1977: 243), second step selected here; isolectotype SING [SING0052924]). Synonym of Diospyros sumatrana Miq.

The species was described by King \& Gamble in two publications in 1905. In Williams (1905b: 428), they listed only one gathering, Curtis 2907 from Junk Seylan, as the original material. In King \& Gamble (1905: 211), additionally, they cited Wray 3508 from Perak (specimens at K [K000792590] and SING [SING0248336, SING0248337]). The lectotype collection was selected by $\mathrm{Ng}$ (1977), and here we complete the typification by designating the unique specimen.

Diospyros ellipsoidea King $\mathcal{E}$ Gamble (1906: 220). Type: Peninsular Malaysia, Perak, Larut, May 1885, King's collector 7689 (lectotype K [K000792361] selected here; isolectotype $\mathrm{K}$ [no barcode]). Accepted name.

In the original description of this species, eight distinct collections from Perak were cited: King's Collector 2233, 3250, 7098, 7269, 7320, 7689, 8215 and Scortechini 1615. Of these gatherings, we found King's Collector 7098 at BM, King's Collector 7269 at BM, E and SING [SING0052926], King's Collector 7689 at K (two specimens), and King's Collector 8215 at K (two specimens) and SING [SING0052928]. No material of King's Collector 2233, King's Collector 3250, King's Collector 7320, and Scortechini 1615 was seen.
Diospyros ferrea (Willd.) Bakh. (Bakhuizen van den Brink 1933: 162); Ebenus buxifolia (Rottb.) Kuntze (1891: 408); Maba buxifolia (Rottb.) Pers. (Persoon 1807: 606); Ehretia ferrea Willd. (Willdenow 1794: 4); Pisonia buxifolia Rottb. (Rottbøll 1783: 536). Type: Malabar, Koenig s.n. (lectotype C [C10010827] selected here; isolectotypes C [C10010826, C10010825, C10010828]). Accepted name.

Four specimens collected by Koenig that could form the original material were found at $\mathrm{C}$; the one annotated by Kostermans as type material is chosen here as the lectotype.

Diospyros flavicans Hiern (1873: 205); Diospyros sumatrana Miq. var. flavicans (Hiern) Bakh. (Bakhuizen van den Brink 1938: 187); "Guatteria flavicans Wall.” (Wallich 1832: 7295) nom. nud. Type: Malaysia, Penang, Porter s.n. [EICH no. 7295] (lectotype K-W [K001127125] selected here). Synonym of Diospyros sumatrana Miq.

For this Hiern name only one specimen was found and is designated here as the lectotype.

Diospyros hendersonii Ridl. (Ridley 1925: 320). Type: Peninsular Malaysia, Pahang, Robinson falls, 18 June 1923, Henderson 11138 (lectotype SING [SING0053009] selected here; isolectotype SING [SING0053008, SING0246542]). Synonym of Diospyros sumatrana Miq.

Among the three specimens of the type collection, all housed at SING, we designate here one as the lectotype.

Diospyros holttumii Bakh. (Bakhuizen van den Brink 1933: 162). Type: Peninsular Malaysia, Kedah, Langkawi, Pulau Dayang Bunting, 23 Aug. 1925, Holtum 15122 (lectotype BO [sheet 1354011] selected here; isolectotypes K [K000792559], SING [SING0053010]). Accepted name.

Here we designate the lectotype among the duplicate specimens of the type gathering.

Diospyros horsfieldii Hiern (1873: 193). Type: Indonesia, Java, Horsfield 1182 (lectotype K [K000792680] selected here). Synonym of Diospyros hasseltii Zoll.

The original publication of Diospyros horsfieldii included the following gatherings, listed together with the matching material we found: Griffith 3620 from 
Malacca (P [P00721556]); Horsfield 1182 from Java (K [K000792680]); Horsfield drawing n. 128 (drawing, K); Leschenault 1669 (not found); Perrottet s.n. (not found).

Diospyros insidiosa Bakh. (Bakhuizen van den Brink 1933: 173). Type: Peninsular Malaysia, Pahang, Pulau Tioman, above Telok Raya, 20 April 1929, Henderson 21730 (lectotype KEP [10914] selected here; isolectotypes K [K000792359], SING [SING0052939, SING0052940]). Accepted name.

Here we designate the lectotype among the four specimens of the type gathering.

Diospyros juppii Merr. (Merrill 1923: 25). Type: British North Borneo (= Sabah), Bettotan River Valley, Sept. 1919, Jupp 727 (lectotype K [K000792700] selected here). Synonym of Diospyros diepenhorstii Miq.

Merrill (1923) cited only one collection in the original publication of Diospyros juppii. Only one specimen was found and is here established as the lectotype.

Diospyros kajangensis Bakh. (Bakhuizen van den Brink 1937: 109). Type: Malaysia, Selangor, Kajang, Sungei Lalang Forest Reserve, 11 March 1930, Symington 22778 (lectotype KEP [no barcode]) selected here; isolectotype SING [SING0053012]). Synonym of Diospyros subrhomboidea King \& Gamble.

This typification only required an herbarium designation. As Symington was based at Kepong Herbarium, we chose the KEP specimen as the lectotype.

Diospyros kingii Bakh. (Bakhuizen van den Brink 1933: 174). Type: Peninsular Malaysia, Perak, Larut, June 1882, King's Collector 3072 (lectotype SING [SING0053013] first step selected by Ng (1977: 225), second step selected here; isolectotype SING [SING0053014]). Accepted name.

A primary lectotypification was made by $\mathrm{Ng}$ (1977), who cited the herbarium where the type is deposited (SING). However, as two duplicates were found at SING, we designate here a unique sheet in a second step lectotypification.

Diospyros kunstleri King E Gamble (1905: 226). Type: Peninsular Malaysia, Perak, Sept. 1883, King's Collector 8229 (lectotype K [K000792587] selected here; isolectotypes E [no barcode], P [P00721599]). Synonym of Diospyros frutescens Blume.
The original publication of Diospyros kunstleri cited three collections: King's Collector 4343, 7633 and 8229, all from Perak. Of the first number we found no specimens and of the second only one sheet at BM. Given the availability of multiple specimens, we chose the third gathering as the type, and among them we chose the best sheet as the lectotype.

Diospyros kurzii Hiern (1873: 162). Type: India, Andaman Islands, Kurz s.n., (lectotype K [K000792478], first step selected by Ng (1977: 227), second step selected here; isolectotypes $\mathrm{K}$ [K000792477, K000792479], M [M0173842, M0173843, M0173844]). Accepted name.

Only one collection was cited in the original publication of Diospyros kurzii. A lectotypification was made by $\mathrm{Ng}$ (1977), as he designated the herbarium (K). However, there are three specimens at $\mathrm{K}$, and the nicest sheet [K000792478] is designated here in a second step lectotypification.

Diospyros latisepala Ridl. (Ridley 1923: 294). Type: Peninsular Malaysia, Perak, Larut, Gunung Pondok, May 1885, Kunstler 7637 (lectotype SING [SING0247435] selected here; isolectotypes $\mathrm{E}$ [no barcode], K [K000792598], L [L0005990]). Accepted name.

In the original description of this taxon, the gatherings mentioned by the author were Foxworthy from Selangor (Kopis and Sungei Buloh), and Kunstler from Perak. The latter was identified with less uncertainty than the former, and additionally duplicates were found in three main herbaria, therefore it was preferred as the lectotype collection. The three duplicates all have the same label with the same information, likely handwritten by the same hand, however it must be noted that the L and SING specimens are attributed to "Dr King's Collector" rather than Kunstler.

Diospyros lucida Wall. ex A.DC. (De Candolle 1844: 233). Type: Singapore, 1822, Wallich s.n. [EICH no. 4127] (lectotype G [G0014201] selected here; isolectotype K-W [K001038208]). Synonym of Diospyros lanceifolia Roxb.

The original publication of this name included the citation of the type material. Here we designate the lectotype specimen. Another specimen filed under the same catalogue number at K, [K000792582], was in fact collected in 1831, and therefore is a different collection. 
Diospyros maingayi (Hiern) Bakh. (Bakhuizen van den Brink 1933: 164); Ebenus maingayi (Hiern) Kuntze (1891: 408); Maba maingayi Hiern (1873: 138). Type: Peninsular Malaysia, Malacca, 25 Oct. 1867, Maingay 1702 [Kew Distrib. no. 976] (lectotype K [K000792370] first step selected by $\mathrm{Ng}$ (1977: 231), second step selected here). Accepted name.

The original description of Maba maingayi included two gatherings: Maingay 976 from Malacca and Beccari 1550 from Borneo. Of the Beccari gathering, several specimens have been identified: FI [FI013006], G [G00341358], K, M [M0173838], NY [NY00334829], P [P00721330], S [S09-33912]). Under Maingay's "Kew Distribution" number series, two different sets of specimens have been found: Maingay 1702 [Kew Distrib. no. 976] (see above) and Maingay 1343 [Kew Distrib. no. 976] (K [K000792371]). In Ng (1977) a lectotypification for "Maingay 976 at K" was made. However, since the Kew Herbarium holds a collection each of the two different Maingay gatherings, a second step lectotypification is made here.

Diospyros malaccensis Bakh. (Bakhuizen van den Brink 1933: 176). Type: Peninsular Malaysia, Perak, Dindings, Sungei Pinang, Pangkor, 24 Dec. 1918, Hamid 2322 (lectotype SING [SING0053018] selected here; isolectotype [SING0053020]). Synonym of Diospyros clavigera C.B.Clarke.

In the original description of this species, two gatherings were mentioned: Ridley 657 from Malacca and Hamid 2322 from Dindings. The former is in fact a Derry collection, somehow attributed to Ridley by Bakhuizen van den Brink, and two specimens were found at SING [SING0053019, SING0246718]. Of the Hamid 2322 collection, we found two specimens, both also at SING, and among them we chose the duplicate with mature fruits as the lectotype.

Diospyros malayana Bakh. (Bakhuizen van den Brink 1933: 163); "Diospyros granulata Korth. ex Bakh." (Bakhuizen van den Brink 1937: 77) (nom. nud., pro syn.); Maba punctata Hiern (1873: 136), non D. punctata Decne. (Decaisne 1834); Ebenus punctata (Hiern) Kuntze (1891: 408). Type: Borneo, Motley 766 (lectotype K [K000792512] selected here). Synonym of Diospyros andamanica (Kurz) Bakh.

Diospyros malayana was the new name in Diospyros for Maba punctata, made necessary by the earlier publication of D. punctata Decne. (Decaisne 1834: 407). In Maba punctata's protologue, Hiern cited the name D. punctata Korth. (nom. illeg., later homonym) in synonymy, from a manuscript by Korthals. Apart from the gathering associated with the name D. punctata Korth., which is "Korthals, MSS. in Hb. Lugd. Batav. Ebenac. n. 15", Hiern cited other specimens, from Gunong Pautie in Borneo: Motley 766 and Beccari 1423. At the Naturalis Herbarium (L, online), we found a series of specimens of D. malayana from Borneo collected by Korthals and labelled by Hiern as: "Maba punctata mihi, Diospyros punctata Korthals MSS., D. granulata Korthals MSS.". These labels are also numbered, but we could not find a number 15 . Instead we found: "1" [L0656828], "17" [L0006023] [L0006024], “18” [L0006020] [L0006021], “19” [L0006025] [L0006026], “21" [L0006022], “22” [L0006019]. Another set of Korthals collections from Borneo are labelled "Diospyros punctata" or "Diospyros granulata" in Korthals' handwriting, without any numbering ([L0006018], [L0656826], "1" [L0656828] (this sheet has both Korthals' and Hiern's labels), [L0656827]). The sheet barcoded [U1275246] might be part of the same gathering. Of the two other collections cited by Hiern, Motley 766 was found at K [K000792512], and Beccari 1423 was found at FI [FI013004], K [K000792511], P[P00721336]. Here we lectotypify the name with the Motley collection at K.

Diospyros malayana Bakh. var. aequabilis Bakh. (Bakhuizen van den Brink 1937: 76). Type: Peninsular Malaysia, Pahang, Kota Glanggi, 4 Aug. 1929, Henderson 22434 (lectotype KEP [10615] selected here; isolectotypes $\mathrm{K}$ [two specimens, no barcodes]). Synonym of Diospyros andamanica (Kurz) Bakh.

In the original description of this taxon (Bakhuizen van den Brink 1937) five distinct gatherings were mentioned, listed here together with the specimens we located: Henderson 22434 (K, KEP [10615], SING [SING0246704]), Henderson 24810 (KEP [10601], SING [SING0246705, SING0246706, SING0245707]), Nur 11806 (KEP [10616], SING [SING0053632]), Boden-Kloss 18721 (SING [SING0052829]), Beltotan 19104 (KEP [238211], SING [SING0052828]). Of Henderson 22434 there are two specimens at $\mathrm{K}$ and one at KEP, selected here as the lectotype.

Diospyros merguensis (Hiern) H.R.Fletcher (1938: 373); Ebenus merguensis (Hiern) Kuntze (1891: 408); Maba merguensis Hiern (1873: 134). Type: Myanmar, Mergui, 10 Jan. 1839, Helfer s.n. [EICH no. 3618] (lectotype K [K000792375] first step designated by Ng (1977: 247), second step selected here; isolectotype $\mathrm{K}$ [K000792387]). Synonym of Diospyros venosa Wall. ex A.DC.

The original description of Maba merguensis included the citation of specimens from Mergui Archipelago 
(Griffith s.n. (in fruit), Helfer 3618), Sumatra (Korthals s.n.), Borneo (Beccari 1670) and likely Java (Blume s.n., Kurl s.n., Hasselt s.n.). A citation of Helfer 3618 in $\mathrm{Ng}$ (1977) as the type of Maba merguensis, constitutes an effective lectotypification, which we complete here with the designation of a unique sheet.

Diospyros nana Bakh. (Bakhuizen van den Brink 1933: 178). Type: Peninsular Malaysia, Perak, Maxwell Hill, Sept. 1888, Wray 3214 (lectotype SING [SING 00052823] selected here). Synonym of Diospyros scortechinii King \& Gamble.

Wray 3214 from Perak, Peninsular Malaysia, is the only collection cited in the original publication of Diospyros nana. We have located just one specimen to date, but cannot exclude the existence of undetected duplicates in other herbaria, as Wray's collections were distributed widely. For this reason, we chose to designate a lectotype.

Diospyros nutans King $\mathcal{E}$ Gamble (1906: 226). Type: Peninsular Malaysia, Perak, Oct. 1882, King's Collector 3513 [lectotype K [K000792353] selected here; isolectotype K [K000792354]). Accepted name.

In the original description of this taxon (King \& Gamble 1906), seven distinct gatherings from Perak in Peninsular Malaysia were cited, here listed with any related specimens that were located: Scortechini 674, 1678; King's Collector 378, 2675 (P [P00721646]), 2987, “3573" (typo for 3513), 7087 (K [K000792355]). Among them, we chose the nicest specimen as the lectotype.

Diospyros oblonga Wall. ex G.Don (1837: 40); Diospyros pilosanthera Blanco var. oblonga (Wall. ex G.Don) $\mathrm{Ng}$ (1977: 237). Type: Peninsular Malaysia, Penang, Aug. 1822, Wallich s.n. [EICH no. 4124] [lectotype KW [K001038214] first step selected by Ng (1977: 237), second step selected here; isolectotype G [G00142427]; possible isolectotype K [K000792585]). Accepted name.

In the herbaria $\mathrm{K}$ and $\mathrm{K}-\mathrm{W}$ there are a total of three specimens labelled Wallich s.n. [EICH no. 4124]. The specimen at K-W [K001038214] has original labels and is the only definite part of the type material. One of the two specimens at $\mathrm{K}$ [K000792584] was collected in 1831 instead of 1822 and is therefore a different collection altogether. The K specimen [K000792585] was collected by Wallich in Penang in 1822 but does not have any of the original labels found on the K-W sheet, therefore we are not entirely sure about its status as an isotype.

Diospyros pachyphylla C.B.Clarke (1882: 568); Diospyros clavigera C.B.Clarke var. pachyphylla (C.B.Clarke) Ridl. (Ridley 1923: 288). Type: Peninsular Malaysia, Malacca, 1867 - 1868, Maingay 3029 [Kew Distrib. no. 974] (lectotype K [no barcode] selected here; isolectotypes K [no barcode], P [P00721665]). Synonym of Diospyros lanceifolia Roxb. var. lanceifolia.

The type collection was named in Clarke's original publication of this name. Here we designate the specimen.

Diospyros pahangensis Bakh. (Bakhuizen van den Brink 1933: 179). Type: Peninsular Malaysia, Pahang, Gunung Senyum, 30 July 1929, Henderson 22296 (lectotype BO [sheet 1351180] selected here; isolectotypes A [A00015422], BM [BM00099762], BO [sheet 1363725], CAS [CAS0033387] K [three specimens, no barcode], KEP [10590], NY [NY00335050], MICH [MICH1192217], P [P00721700] and SING [SING0052340]). Synonym of Diospyros apiculata Hiern.

The type collection was designated in the original publication of this name. Here we designate the unique lectotype.

Diospyros palembanica Bakh. (Bakhuizen van den Brink 1933: 180). Type: Indonesia, Sumatra, Palembang, 7 May 1917, Dumas 1560 (lectotype BO [sheet 1353448] selected here; isolectotypes BO [sheets 1353425, 1353449]). Synonym of Diospyros pauciflora King \& Gamble.

The type gathering was the only listed in the original publication of Diospyros palembanica. Three specimens of Dumas 1560 were found, all at BO. Here we designate the unique lectotype.

Diospyros paniculata Dalzell (1852: 109). Type: India, Syhadree mountains, near Chorla-ghât, Dalzell s.n. (lectotype K [K000792420] first step selected by Singh (2005: 191), second step selected here; isolectotypes K [K000792421, K000792422]). Accepted name

The original description of Diospyros paniculata provided the locality, which is in today's Western Ghats of India. Three specimens potentially belonging to the original material were found at $\mathrm{K}$ and the one that 
best represents the key characters of the species has been designated as the lectotype.

Diospyros penangiana King E Gamble (1906: 227). Type: Peninsular Malaysia, Penang, Feb. 1890, Curtis 2221 (lectotype K [K000792360] selected here; isolectotypes BM [no barcode], L [L0538545], SING [SING0052856, SING0247978]). Accepted name.

Curtis 2221 was the only collection cited in the original publication of Diospyros penangiana. Here we designate the lectotype among the several duplicates. Other specimens of Curtis 2221 were collected in February 1892 (KEP [80759] [SING [SING 0052857, SING0247979]) and are therefore excluded from the type material.

Diospyros pendula Hasselt ex Hassk. (Hasskarl 1848: 468). Type: Indonesia, Java, Bantam, Monte Pulassarie, van Hasselt s.n. (lectotype L [L2665950 left side only], selected here). Accepted name.

The original material associated with this name was collected by van Hasselt from Monte Pulassarie in Bantam, Java, in June, at an elevation of $4000 \mathrm{ft}$ asl, with the local name of Kikelèr. Only one such specimen was found, and it is the left-hand side sample on the sheet L [L2665950].

Diospyros perakensis Bakh. (Bakhuizen van den Brink 1933: 181). Type: Peninsular Malaysia, Perak, Larut, 1889, Wray 501 (lectotype SING [SING00052423] selected here; isolectotypes SING [SING00052421, SING00052422]). Synonym of Diospyros dictyoneura Hiern.

In the original description of this species the only gathering cited was Wray 501 from Perak. There are three specimens of this gathering at SING. The specimen with male flowers is designated here as the lectotype.

Diospyros pilosanthera Blanco (1837: 304). Type: Philippines, Batangas Prov., Luzon, 11 Feb. 1915, Ramos, Species Blancoanae No. 820 (neotype US [US00623728] first step selected by Merrill, Sp. Blancoan. (1918: 302), second step selected here). Synonym of Diospyros oblonga Wall. ex G.Don.

Since Blanco's original material is not available, and his names did not have types, Merrill (1918) went on to neotypify those species, including Diospyros pilosanthera. Here we complete the neotypification by designating a single type sheet.

Diospyros pseudomalabarica Bakh. (Bakhuizen van den Brink 1933: 182). Type: Peninsular Malaysia, Pahang, Raub, 1 July 1927, Foston 12865 (lectotype KEP [10627] selected here; isolectotype SING [SING0052424]). Synonym of Diospyros areolata King \& Gamble.

In the original description of this species two gatherings were cited, Haniff $\mathcal{E}$ N Nur 3496 from Pulau Penang and Foston 12865 from Pahang. We located a sheet of Haniff $\mathcal{E} \mathcal{O}^{2}$ Nur 3496 at SING [SING0246332], and we designate it here as the lectotype the specimen of Foston 12865 housed at KEP.

Diospyros pubicalyx Bakh. (Bakhuizen van den Brink 1933: 182). Type: Lower Siam (= Thailand or Peninsular Malaysia), 16 April 1919, Hamid C. F. 3827 (lectotype SING [SING0052425] selected here; isolectotype K [K001089523]). Synonym of Diospyros montana Roxb.

The type collection of Diospyros pubicalyx was designated in the original publication. Here we finalise the typification by designating an individual specimen. Here we also correct the epithet's spelling from "pubicalix" to "pubicalyx", following article 60.6 of the International Code of Nomenclature for algae, fungi, and plants (Turland et al. 2018).

Diospyros pubicarpa Ridl. (Ridley 1923: 286). Type: Peninsular Malaysia, Pahang, Bentong, Jemampang, 6 Jan. 1920, Ahmad 5093 (lectotype KEP [10937] selected here; isolectotype K [K000792599]). Synonym of Diospyros kurzii Hiern.

In the original publication of this taxon, the only gathering mentioned was Foxworthy s.n., Pahang, Bentong Jemampang, native name Hidang Kelawar. Only one specimen with matching label data, apart from the collector name, was found, and is here designated as the lectotype.

Diospyros pyrifera Ridl. (Ridley 1908: 117, as 'pyriferus'). Type: Singapore, Bukit Timah, Oct. 1896, Ridley 8101 (lectotype SING [SING0012222] selected here; isolectotype $\mathrm{K}$ [no barcode]). Synonym of Diospyros diepenhorstii Miq.

In the original description of this species, Ridley listed a number of his own collections, all from Bukit Timah 
in Singapore, namely Ridley 8101, 10847 [K 000792358 ] , [ [SING0012224], 10442 [SING0012225], 6118 [SING0012223], and 8114 [SING0012226]. The SING specimen of Ridley 8101 is designated here as the lectotype.

Diospyros reflexa King $\mathcal{E}$ Gamble (1905: 227). Type: Peninsular Malaysia, Perak, near Gunung Bubu, May 1885, King's Collector 7676 (lectotype K [K000792569] selected here; isolectotype $\mathrm{P}$ [P00721682]). Synonym of Diospyros pyrrhocarpa Miq.

In the original publication of this species, two gatherings from Perak, Peninsular Malaysia were mentioned: King's Collector 7676 (K [K000792569], P [P00721682]) and King's Collector 7747 (K [K000792568, K000792570]). Two specimens of each gathering were found. They are all morphologically similar, and we chose to lectotypify from the more widely spread collection.

Diospyros retrofracta Bakh. (Bakhuizen van den Brink 1933: 183). Type: Lower Siam, Pungah, 7 Dec. 1918, Haniff E Nur 3984 (lectotype BO [no barcode] selected here; isolectotype K [K000792535]). Synonym of Diospyros bejaudii Lecomte.

In the original description of this taxon, two distinct gatherings were mentioned: Henderson 23013 from Perlis and Haniff $\mathcal{E}$ Nur 3984 from Southern Thailand. Of the first gathering, specimens were found at A [A00056456], KEP [11501], K [K000972564, K000972563] and SING [SING0052831]; of the second gathering specimens were found at BO and K [K000792535]. The BO specimen of the Haniff $\mathcal{E}$ Nur 3984 is selected here as the lectotype.

Diospyros rigida Hiern (1873: 257). Type: Malaysia, Sarawak, Mt Mattang, July 1866, Beccari P.B. 2285 (lectotype FI [FI013000] selected here; isolectotype K [K000792647]). Accepted name.

The original description of this species included the citation of a single collection, Beccari P.B. 2285 from Borneo. Here we designate the lectotype specimen.

Diospyros rufa King \& Gamble (1905: 228). Type: Peninsular Malaysia, Perak, Larut, Oct. 1884, King's Collector (Kunstler) 6712 (lectotype SING [SING0052835] selected here; isolectotypes BM [no barcode], K [K000792577, K000792578]). Accepted name.
In the original description of this taxon, four distinct numbers under the King's Collector series were cited: 3330, 4945, 5409 and 6712, all from Perak in Peninsular Malaysia. Of these gatherings, only a few specimens could be found, including a sterile specimen of King's Collector 3330 [SING0052833], duplicates of King's Collector 5409 at E and SING [SING0052834], and fruiting specimens of King's Collector 6712 at BM, K and SING.

Diospyros sapotoides Kurz (1873: 88). Type: Myanmar, Pegu, Kurz 3013 (lectotype K [K000792449] first step selected by Hiern (1873: 206), second step selected here; isolectotypes K [K000792450, K000792451, K000792452]). Synonym of Diospyros oblonga Wall. ex G.Don.

Diospyros sapotoides was described in 1873 as a new species from Pegu, to which Hiern (1873: 206) associated the collection Kurz 3013, making it a first step lectotypification. Here we designate as the lectotype one of four specimens found at $\mathrm{K}$.

Diospyros scortechinii King E G Gamble (1906: 212). Type: Peninsular Malaysia, Perak, April 1884, Scortechini 377 (lectotype K [K000792362] selected here; isolectotype BM [no barcode]). Accepted name.

In the original description of this taxon, eight distinct gatherings from Perak, Peninsular Malaysia were mentioned: Curtis 2092, King's Collector 2407, 4126, 5002, 5296, 6356, Scortechini 377, and Wray 638. The syntypes we found are Curtis 2092 at SING [SING0052864], King's Collector 2407 at BM [no barcode], King's Collector 4126 at E (two sheets) and SING [SING0052868], King's Collector 5296 at BM [no barcode], K [K000792363] and SING [SING0052866], King's Collector 6356 at SING [SING0052903], and Scortechini 377 at BM [no barcode] and K [K000792362]. We could not find any sheet of King's Collector 5002.

Diospyros singaporensis Bakh. (Bakhuizen van den Brink 1933: 185). Type: Singapore, Cult. in Bot. Gard. 13 Jan. 1920, Deshmukh s.n. (lectotype SING [SING0248193] selected here). Accepted name.

This species was described from a female tree cultivated at Singapore Botanic Gardens. In a later publication, Bakhuizen van den Brink (1937: 110) specified that his original description was made from specimens collected on 13 Jan. 1920 and 14 June 1924 (the latter by Nur). We found two sterile specimens of Nur's 1924 collection (SING [SING0052859, 
SING52860]). We also found a specimen of Diospyros singaporensis collected on 13 Jan. 1920 by Deshmukh. The label used on this sheet suggests the provenance to be Penang Botanic Gardens. Since Deshmukh was based in Singapore and the species, date and type of collection (from cultivated) all matched with Bakhuizen van den Brink's data, we believe this to be the actual flowering specimen vouchered at Singapore Botanic Gardens from the same female tree as the 1920 collection. As this is also the only flowering specimen of the three retrieved, we designate it here as the lectotype.

Diospyros styraciformis King $\mathcal{E}$ Gamble (1905: 216). Type: Singapore, Bukit Timah, 1892, Ridley 3787 (lectotype SING [SING0052847] selected here; isolectotype BM [no barcode]). Accepted name.

The original publication of Diospyros styraciformis cited two collections: Ridley 3787 from Singapore and Maingay s.n. [Kew Distrib. no. 969] from Malacca. We found two specimens of the Maingay gathering, one at L [L0931220] lacking the original label, and one at $\mathrm{K}$ [K000792580], which however was collected in Singapore and annotated as Griffith 3637 and Maingay 2644A. For clarity and convenience, a specimen from the Ridley gathering is chosen as the lectotype.

Diospyros subrhomboidea King E Gamble (1906: 209). Type: Peninsular Malaysia, Perak, Larut, Feb. 1885, King's Collector 7302 (lectotype K [K000792366] selected here; isolectotypes BO [sheet 1678289], E [no barcode], P [P00721740]). Accepted name.

In the original description of this taxon, three distinct collections were mentioned: King's Collector 7302 and Wray 4055 from Perak in Peninsular Malaysia, and Forbes 2004 from Sumatra, Indonesia. We could not find any specimens of Wray 4055. One specimen of Forbes 2004 was found at L [L0006071] and four specimens of King's Collector 7302 were seen (BO [sheet 1678289], E [no barcode], K [K000792366], P [P00721740]. According to $\mathrm{Ng}$ (1977) the gathering of King's Collector 7302 might contain specimens of Diospyros buxifolia. Likewise, Forbes 2004 is rather too similar to D. buxifolia. While we confirm the status of this species, we lectotypify Diospyros subrhomboidea on one of the specimens at $\mathrm{K}$ that are available for study.

Diospyros subrigida Hochr. (Hochreutiner 1905: 24). Type: Malaysia, Sarawak, 1 Dec. 1904, Hochreutiner 17 (lectotype G [G00341346] selected here; isolectotype K [K000792648]). Synonym of Diospyros rigida Hiern.
In the original description of this species, the author cited only one gathering: Hochreutiner 17, from Sarawak, Borneo. There are two specimens of this gathering at $\mathrm{G}$ and $\mathrm{K}$. As Hochreutiner's types are housed at G (Stafleu \& Cowan 1976), we prioritised this herbarium for our choice of a lectotype. The specimen deposited at $\mathrm{G}$ with barcode [G00341345] and with a (not original) "holotype" label, is in fact Hochreutiner $17 \mathrm{a}$, and therefore not a type.

Diospyros sumatrana Miq. (Miquel 1852: 203); Ebenus sumatrana (Miq.) Kuntze (1891: 408). Type: Indonesia, Sumatra, Angkola Sup. Distr., Junghuhn s.n. (lectotype L [L0006080] selected here; possible isolectotypes L [L0006078, L0006079, L0006081], U [U0001660]). Accepted name.

The original material listed in the protologue included collections made by Junghuhn in Angkola, Sumatra. We found only one specimen that clearly matched this information, plus four other specimens that could be isotypes and have been labelled as such by Bakhuizen van den Brink.

Diospyros toposioides King E Gamble (1905: 223); Diospyros toposia Buch.-Ham. var. toposioides (King \& Gamble) Phengklai (1978: 36). Type: Peninsular Malaysia, Perak, Lumut, King's Collector 8242 [lectotype $\mathrm{K}$ [K000792572] selected here; isolectotype $\mathrm{K}$ [K000792573]). Accepted name.

The original publication of this species included the citation of nine collections from Perak, Peninsular Malaysia. The following is an enumeration of King \& Gamble's material and the specimens we have found during our investigation. King's Collector 4106 (SING [SING0052842, SING0248607, SING0248608]), King's Collector 4361 (no specimens found), King's Collector 4889 (K [K000792571]), King's Collector 5769 (BM (no barcode), E (no barcode), P [P00721755]); King's Collector 8242 (K [K000792572, K000792573]), King's Collector 8357 (no specimens found), Scortechini s.n. (SING [SING0248551, SING0248552, SING0248556]), Ridley 10302 (E [no barcode], SING [SING0052841]), Ridley 3079 (SING [SING0249481]). The lectotype was chosen for its better state of preservation and completeness.

Diospyros transitoria Bakh. (Bakhuizen van den Brink 1933: 186). Type: Lower Siam (= Thailand), Pulau Panji, 16 Dec. 1918, Haniff E Nur 4060 (lectotype BO [sheet 680068] selected here; isolectotypes $\mathrm{K}$ [K000792523], SING [SING0052843]). Accepted name. 
In the original description of this taxon, Bakhuizen van den Brink cited two distinct gatherings: Haniff $\mathcal{E}^{\circ}$ Nur 4060 from "Lower Siam" and Curtis 2626 from Kedah, Peninsular Malaysia. We found one specimen of Curtis 2626 at SING ([SING0052845]) and three of Haniff $\mathcal{E}$ Nur 4060. The BO specimen of Haniff $\mathcal{E}^{2}$ Nur 4060 is selected here as the lectotype based on the author's affiliation.

Diospyros truncata Zoll. E $\mathcal{F}^{\circ}$ Moritzi var. major Bakh. (Bakhuizen van den Brink 1938: 230). Type: Peninsular Malaysia, Pahang, Cameron Highland, 7 April 1930, Henderson SF 23471 (lectotype BO [sheet 1681480] selected here; isolectotypes KEP [12430], SING [SING0248627]). Accepted name.

In the original description of this taxon seven distinct collections from Pahang, Peninsular Malaysia were mentioned. Here is a short summary of the specimens we gathered: Burkill $\mathcal{F}^{\circ}$ Holtum 7851 (BO, KEP [12435], SING [SING0248624, SING0248626]), Henderson 11640 ( $\mathrm{BO}, \mathrm{KEP}$ [12427], SING [SING0248623]), Henderson $\mathcal{E}$ Whithy 18047 (BO, KEP [12434], SING [SING0248625]), Symington 20944 (BO, KEP [12432]), Symington 20948 (BO, KEP [12429]), Henderson SF 23471 (BO, KEP [12430], SING [SING0248627]), Osman 24344 (BO, KEP [12428]). In choosing the lectotype, we have given preference to the best specimen among those at $\mathrm{BO}$.

Diospyros trunciflora Ridl. (Ridley 1911: 67). Type: Peninsular Malaysia, Perak, Lenggong, Aug. 1904, Ridley 14579 (lectotype SING [SING0053634] selected here). Synonym of Diospyros cauliflora Blume.

In the original description of this taxon, Ridley provided the locality of the type material, Lenggong, and cited the following as additional material: Ridley 9447, Ridley 9716 and Goodenough 1858. We could only locate one sheet from Lenggang, at SING, and we designate it as the lectotype.

Diospyros tubicalyx Ridl. (Ridley 1923: 285). Type: Peninsular Malaysia, Pahang, Lubok Pakau, 16 April 1919, Yeop 3166 (lectotype SING [SING0248202] first step selected by Ng (1977: 243), second step selected here; isolectotypes KEP [11915], SING [SING0248504]). Synonym of Diospyros sumatrana Miq.

The original material cited by Ridley in the protologue of Diospyros tubicalyx is Foxworthy s.n. from Lubok Pakau, in Peninsular Malaysia. No such collection was found, but we came across a collection made by Yeop in 1919 from the same locality and the same period in which Foxworthy would have been actively collecting in Peninsular Malaysia. Yeop and Foxworthy were both based at the Forest Department of the Malay Peninsula (van Steenis-Kruseman 1950) and collected under the same number series. For these reasons, we agree with $\mathrm{Ng}$ (1977) in believing that Yeop's collection is in fact the material that was examined by Ridley, and here we complete his typification.

Diospyros velutinosa Bakh. (Bakhuizen van den Brink 1941: 399); Diospyros vestita Bakh. (Bakhuizen van den Brink 1933: 187) (nom. illegit. later homonym). Type: Peninsular Malaysia, Pahang, Gunung Senyum, 30 July 1929, Henderson 22290 (lectotype BO [sheet 1681577] selected here; isolectotypes BO [sheet 1680145], KEP [11515], MICH [1192226], NY [00334765], SING [SING0249462]). Synonym of Diospyros sumatrana Miq.

Diospyros velutinosa is the name with which Bakhuizen van den Brink validated the species he previously called $D$. vestita, a later homonym of a Benoist species. The type collection was designated in the protologue, here we designate the unique lectotype.

Diospyros venosa Wall. ex A.DC. var. olivacea (King E Gamble) Ng (1977: 247); Diospyros olivacea (King \& Gamble) H.R.Fletcher (1938: 376); Diospyros hermaphroditica (Zoll.) Bakh. var. olivacea (King \& Gamble) Bakh. (Bakhuizen van den Brink 1937: 88); Diospyros hermaphroditica (Zoll.) Bakh. var. olivacea (King \& Gamble) Bakh. forma velutina Bakh. (Bakhuizen van den Brink 1937: 88); Maba olivacea King \& Gamble in F.N.Williams (1905a: 227; King \& Gamble 1905: 204). Type: Peninsular Malaysia, Perak, July 1885, King's Collector 7877 (lectotype K [K000792373] first step selected by Ng (1977: 247), second step selected here; isolectotypes BM [no barcode], SING [SING0052824]). Accepted name.

The original description of Maba olivacea included three syntypes: King's collector 7877 and Wray 1269 from Perak, and Curtis 1661 from Langkawi. A preliminary type designation was made by $\mathrm{Ng}$ (1977), who cited "King's Coll. 7877 (SING, K) Batang Padang, Perak". Here we finalise the lectotypification. No specimens of Curtis 1661 have been found in the herbaria we visited.

Diospyros wrayi King $\mathcal{E}$ Gamble (1905: 209). Type: Peninsular Malaysia, Perak, Larut, April 1882, King's Collector 2993 (lectotype K [K000792600] selected here; isolectotype P [P00721775]). Synonym of Diospyros kurzii Hiern. 
The original publication of Diospyros wrayi included a number of gatherings from Perak, here listed with the matching specimens we found: Scortechini s.n. [not found], Wray 2764 [SING0052837, SING0249404], Wray 3272 [SING0052838], Wray 3955 [SING0052836, SING0249402, SING0249403, SING0249405], King's Collector 2076 [K000792601], King's Collector 2993 [K000792600, P00721775]. The designated lectotype was chosen for the condition of the specimen and the existence of an isotype in another herbarium.

Diospyros yeobii Bakh. (Bakhuizen van den Brink 1933: 188). Type: Peninsular Malaysia, Pahang, Sungei Rompin, Batu Hampar, 17 May 1919, Yeob 3229 (lectotype KEP [11898] selected here; isolectotypes K [K000792579], SING [SING0052862]). Accepted name.

The original publication of this name listed only one gathering. Here we designate a single lectotype among the three sheets located. The orthography is corrected from the original spelling "yeobi", according to Art. 60.8 (b) of the International Code of Nomenclature (Turland et al. 2018).

Maba buxifolia Pers. var. rhomboidea Ridl. (Ridley 1923: 281). Type: Peninsular Malaysia Penang, Province Wellesley, Kubang Ulu, June 1890, Curtis s.n. (lectotype SING [SING0246487] selected here). Synonym of Diospyros ferrea (Willd.) Bakh.

In the original description of this variety, the original material cited consisted of a Curtis collection from "Province Wellesley, Kubang Ulu". The only matching specimen we found is here designated as the lectotype.

Maba perakensis King $\mathcal{E}$ Gamble (1905: 205). Type: Peninsular Malaysia, Selangor, Fraser Hill, Sept. 1922, Burkill E $\mathcal{F}^{\circ}$ Holttum 7855 (neotype K [no barcode] selected here). Synonym of Diospyros confertiflora (Hiern) Bakh.

In the original description of this taxon, three distinct gatherings from Perak, Peninsular Malaysia were mentioned: King's Collector 3945, 5519 and Wray 3130. We could not find any specimens of these gatherings. As no original specimens or illustrations are available, the specimen Burkill $\mathcal{E}^{2}$ Holtum 7855 (K) is designated as the neotype.

Maba racemosa Ridl. (Ridley 1925: 320). Type: Peninsular Malaysia, Negeri Sembilan, Bukit Tang 1923, Nur 11806 (lectotype KEP [10616] selected here; isolectotypes BM [no barcode], K [K000792374], SING [SING0053632]). Synonym of Diospyros andamanica (Kurz) Bakh.

The type associated with this name was designated in the original description. Here we designate the unique lectotype among the duplicates we located.

\section{Acknowledgements}

The authors are grateful to the curators of the BM, $\mathrm{BO}, \mathrm{E}, \mathrm{K}, \mathrm{KEP}, \mathrm{L}, \mathrm{P}$ and SING herbaria for access to the specimens used in the present study. In FRIM, we would like to thank Dr Ruth Kiew, Dr Richard Chung and Sarah Nabila binti Rosli for all their help. We are grateful to Heather Lindon (RBG, Kew) and an anonymous reviewer for their suggestions. The first author was supported by a Visiting Research Fellowship at FRIM which is gratefully acknowledged.

Open Access This article is licensed under a Creative Commons Attribution 4.0 International License, which permits use, sharing, adaptation, distribution and reproduction in any medium or format, as long as you give appropriate credit to the original author(s) and the source, provide a link to the Creative Commons licence, and indicate if changes were made. The images or other third party material in this article are included in the article's Creative Commons licence, unless indicated otherwise in a credit line to the material. If material is not included in the article's Creative Commons licence and your intended use is not permitted by statutory regulation or exceeds the permitted use, you will need to obtain permission directly from the copyright holder. To view a copy of this licence, visit http://creativecommons.org/ licenses/by/4.0/.

\section{References}

Bakhuizen van den Brink, R. C. (1933). Enumeration of Malayan Ebenaceae. Gard. Bull. Straits Settlem. 7: 161 - 189 \& Pl. 48 - 50.

(1936 - 1955). Revisio Ebenacearum Malayensium. Bull. Jard. Bot. Buitenzorg ser. 3, 15: 1 -515. Published in parts. Vol. 1: 1 - 49 (1936). Vol. 2: 49 - 178 (1937). Vol. 3: 179 - 368 (1938). Vol. 4: 369 - 515 (1941). Vol. 5: i - xx, pl. 1 - 92 (1955).

Blanco, F. M. (1837). Flora de Filipinas. Manila.

Blume, C. L. von (1826). Bijdragen tot de Flora van Nederlansch Indie Pt. 13. Lands Drukkerij. Batavia. (1827). Bijdragen tot de Flora van Nederlansch Indie Pt. 17. Lands Drukkerij. Batavia.

Boden Kloss, C. (1926). Spolia Mentawiensia. Bull. Misc. Inform., Kew 1926: 56 - 94. 
Chong, K. Y., Tan, H. T. W. \& Corlett, R. T. (2009). A Checklist of the total vascular plant flora of Singapore, Native, Naturalised and Cultivated species. National University of Singapore, Singapore.

Clarke, C. B. (1882). Ebenaceae. In: J. D. Hooker, Flora of British India, Vol. 3: 549 - 572. Reeve, London.

Dalzell. N.A. (1852). Contributions to the Botany of Western India. Hooker's J. Bot. Kew Gard. Misc. 4: 107 - 114.

Decaisne, J. (1834). Description d'un herbier de l'ile de Timor, faisant partie des collections botaniques du Museum d'Histoire Naturelle. Nouv. Ann. Mus. Hist. Nat. ser. 3. s: $333-501$.

De Candolle, A. (1844). Ebenaceae. In: A. De Candolle (ed.), Prodromus Systematis Naturalis Regni Vegetabilis 8: 209 - 243. Treuttel \& Würtz, Parisiis.

Don, G. (1837). A General History of the Dichlamydeous Plants 4. J. G. and F. Rivington et al., London.

Elmer, A. D. E. (1908). Three Score of New Plants. Leafl. Philipp. Bot. 2: $463-525$.

Fletcher, H. R. (1938). Ebenaceae. In: A. F. G. Kerr (ed.), Florae Siamensis Enumeratio 2: 363 - 384. The Bangkok times press, Bangkok.

Hasskarl, J. K. (1848). Plantae Javanicae Rariores Sumptibus A. Foerstner, Berlin.

Hiern, W. P. (1873). A Monograph of Ebenaceae. Trans. Cambridge Philos. Soc. 12, 2: 27 - 300.

Hochreutiner, B. P. G. (1905). Catalogus Bogoriensis Novus. Bull. Inst. Bot. Buitenzorg 19: 1 - 48.

Keng, H. (1990). The Concise Flora of Singapore, Gymnosperms and Dicotyledons. Singapore University Press, Singapore.

King, G. \& Gamble, J. S. (1905). Materials for a Flora of the Malayan Peninsular. J. Asiat. Soc. Bengal, Pt. 2, Nat. Hist. 74 (1): 1 - 386.

\& _ (1906). Materials for a Flora of the Malayan Peninsular. J. Asiat. Soc. Bengal, Pt. 2, Nat. Hist. 74 (2): 1 - 908.

Kuntze, O. (1891). Revisio Generum Plantarun 2. A. Felix, Leipzig.

Kurz, S. (1870). Report on the vegetation of the Andaman Islands, ed. 2. Office of Superintendent of Government Printing, Calcutta.

(1871). On some new or imperfectly known Indian Plants, continuation from Journal, Vol. XXXIX, Part II, pp. 61 - 91. J. Asiat. Soc. Bengal, Pt. 2, Nat. Hist. 40: $45-78$.

(1873). New Burmese Plants, part II. J. Asiat. Soc. Bengal, Pt. 2, Nat. Hist. 42 (2): 59 - 110.

(1876). A Sketch of the Vegetation of the Nicobar Islands. J. Asiat. Soc. Bengal, Pt. 2, Nat. Hist. $45: 105-164$.

Lecomte, M. H. (1929). Quelques Ébénacées nouvelles de L'Indo-Chine. Bull. Mus. Natl. Hist. Nat., sér. 2, 1 (1929) $430-432$.

Merrill, E. D. (1909). New or Noteworthy Philippine Plants, VII. Philipp. J. Sci. C 4: $247-330$.
(1918). Species Blancoanae. Bureau of Printing, Manila.

(1923). New or Noteworthy Bornean Plants. Part III. J. Malayan Branch Roy. Asiat. Soc. 1: $22-45$.

Miquel, F. A. W. (1852). Ebenaceae. In: F. A. W. Miquel (ed.), Plantae Junghuhnianae. A. W. Sythoff, Leiden, J. B. Bailliere, Paris.

(1861). Flora van Nederlandsch Indie, Eerste Bijvoegsel, suppl. 1: 280 - 617. C. G. van der Post, Amsterdam.

Ng, F. S. P. (1977). Notes on the Systematy of Malayan Phanerogams XXVI. Ebenaceae. Malaysian Forester 40: $210-248$.

Oliver, D. (1894). Diospyros bilocularis. Hooker's Icon. Pl. 24: t. 2336.

Persoon, C. H. (1807). Synopsis Plantarum, part 2. C. F. Cramer, Paris.

Phengklai, C. (1978). Ebenaceae of Thailand. Thai Forest Bull., Bot. 11: 1 - 103.

(1981). Ebenaceae. In: Flora of Thailand Vol. 2, part 4, pp 181 - 392. Applied Scientific Research Corporation of Thailand, Bangkok.

Ridley, H. N. (1893). On the Flora of the Eastern Coast of the Malay Peninsula. Trans. Linn. Soc. London, Bot. 3: $267-408$.

(1908). New or rare Malayan Plants. J. Straits Branch Roy. Asiat. Soc. 50: 111 - 152.

(1911). A Scientific Expedition to Temengoh, Upper Perak. J. Straits Branch Roy. Asiat. Soc. 57: 5 122.

(1923). The Flora of the Malay Peninsula, Vol. 2. Government of the Straits Settlements and Federated Malay states. L. Reeve \& Co., London.

(1925). The flora of the Malay Peninsula, Vol. 5. Government of the Straits Settlements and Federated Malay states. L. Reeve \& Co., London.

Rottbøll, C. F. (1783). Beskrivelse over nogle Planter fra de Malebariske Rofter. Nye Saml. Kongel. Danske Vidensk. Selsk. Skr. 2: 525 - 546.

Singh, V. (2005). Monograph on Indian Diospyros L. (Persimmon, Ebony) Ebenaceae. Botanical Survey of India, Kolkata.

Stafleu, F. A. \& Cowan, R. S. (1976). Taxonomic literature, ed. 2, Vol. 1: A - G. Bohn, Scheltema \& Holkema, Utrecht.

Thiers, B. [continuously updated]. Index Herbariorum: A global directory of public herbaria and associated staff. New York Botanical Garden's Virtual Herbarium. http://sweetgum.nybg.org/science/ih/.

Turland, N. J., Wiersema, J. H., Barrie, F. R., Greuter, W., Hawksworth, D. L., Herendeen, P. S., Knapp, S., Kusber, W.-H., Li, D.-Z., Marhold, K., May, T. W., McNeill, J., Monro, A. M., Prado, J., Price, M. J. \& Smith, G. F. (eds) (2018). International Code of Nomenclature for algae, fungi, and plants (Shenzhen Code) adopted by the Nineteenth International Botanical Congress Shenzhen, China, July 2017. Regnum Veg. 159. 
Glashütten: Koeltz Botanical Books. https:// doi.org/10.12705/Code.2018

Turner, I. M. (1993). The Names Used for Singapore Plants Since 1900. Gard. Bull. Singapore 45: 1 - 287. (1995). A Catalogue of the Vascular Plants of Malaya. Gard. Bull. Singapore 47 (1 - 2): 1 - 757.

van Steenis-Kruseman, M. J. (1950). Cyclopedia of Collectors. In: C. G. G. J. van Steenis (ed.), Flora Malesiana, Vol. 1. Noordhoff-Kolff, Djakarta.

Wallich, N. (1832). A numerical list of dried plants in the East India Company's Museum collected under the superintendence of Dr Wallich of the Company's botanic garden at Calcutta. n. 7295. East India Company, Calcutta \& London.

Willdenow, C. L. von (1794). Phytographia, part 4. Sumptibus Wolfgang Walther, Erlangen.
Williams, F. N. (1905a). Liste des Plantes Connues du Siam. Bull. Herb. Boissier, sér. 2, 5: 216 - 227.

(1905b). Liste des Plantes Connues du Siam. Bull. Herb. Boissier, sér. 2, 5: 428 - 439.

Wong, H. F., Tan, S. Y., Koh, C. Y., Siow, H. J. M., Li, T., Heyzer, A., Ang, A. H. F. Mirza Rifqi bin Ismail, Srivathsan, A. \& Tan, H. T. W. (2013). Checklist of the plant species of Nee Soon swamp forest, Singapore: bryophytes to angiosperms. Singapore.

\section{Publisher's Note}

Springer Nature remains neutral with regard to jurisdictional claims in published maps and institutional affiliations. 